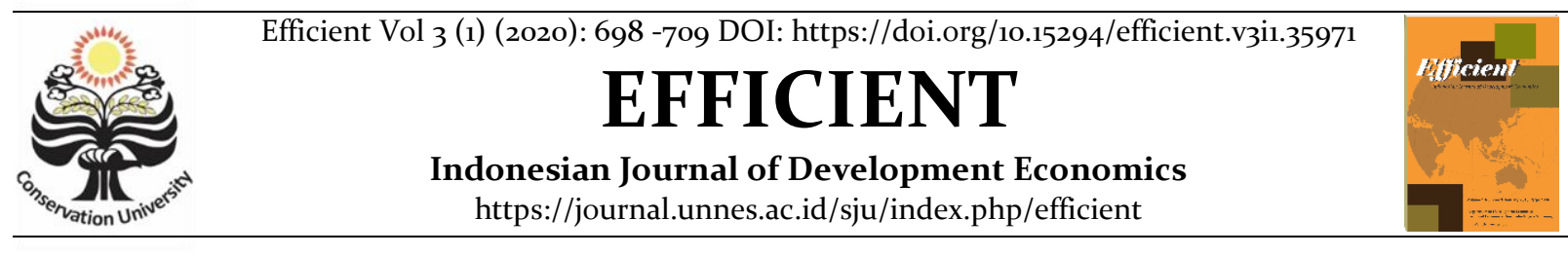

\title{
Strategy of Implementation Highest Medium Rice Retail Price Policy
}

\author{
Riyan Nur Rifai \\ Jurusan Ekonomi Pembangunan, Fakultas Ekonomi, Universitas Negeri Semarang \\ Permalink/DOI: https://doi.org/10.15294/efficient.v3i1.35971 \\ Received: July 2019 ; Accepted: October 2019 ; Published: January 2020

\begin{abstract}
The purpose of this study is to find out what factors influence the implementation of the policy and formulate the strategy for implementing the policy. The main data type is primary data and is equipped with secondary data. Data collection methods are used interviews, questionnaires and literature studies. Research analysis used a SWOT analysis tool. Based on the results of the study that internal factors and external factors that influence the strength of internal factors consisting of easily published policies, adequate human resources, policy objectives and clear sanctions for policy violators. The weakness side is that the level of supervision is not optimal, the implementer rejects the policy, the highest retail price level is not right and the policy information has not been clearly conveyed. Whereas the opportunity side of external factors is the ability to increase rice stocks with imports, the government's readiness to fill rice stocks in the market and the public's encouragement to maintain stability in rice price stability. The threat side is the availability of rice from limited farmers, disruption of rice production factors and a long rice distribution chain. The right strategy used today is a defensive strategy.
\end{abstract}

Keywords: Highest Retail Price, Rice, Policy Implementation

\begin{abstract}
Abstrak
Tujuan penelitian ini untuk mengetahui faktor-faktor apa saja yang mempengaruhi implementasi kebijakan tersebut dan merumuskan strategi implementasi kebijakan tersebut. Jenis data utama digunakan data primer dan dilengkapi data sekunder. Metode pengambilan data digunakan wawancara, kuisioner dan studi kepustakaan. Analisis penelitian digunakan alat analisis SWOT. Berdasarkan hasil penelitian bahwa faktor internal dan faktor eksternal yang mempengaruhi yaitu dari sisi kekuatan pada faktor internal terdiri dari kebijakan mudah dipublikasikan, sumber daya manusia memadai, tujuan kebijakan dan sanksi jelas bagi pelanggar kebijakan. Sisi kelemahan yaitu tingkat pengawasan belum optimal, pelaksana menolak kebijakan, tingkat harga eceran tertinggi belum tepat dan informasi kebijakan belum tersampaikan dengan jelas. Sedangkan sisi peluang dari faktor eksternal yaitu kemampuan menambah persediaan beras dengan impor, kesiapan pemerintah untuk mengisi persediaan beras di pasar dan dorongan masyarakat untuk menjaga stabilitas stabilitas harga beras. Sisi ancaman yaitu ketersediaan beras dari petani terbatas, gangguan faktor produksi beras dan rantai distribusi beras panjang. Strategi yang tepat digunakan saat ini yaitu strategi defensif.
\end{abstract}

Kata Kunci: Harga Eceran Tertinggi, Beras, Implementasi Kebijakan

How to Cite: Rifai, R. (2020). Strategy of Implementation Highest Medium Rice Retail Price Policy. Efficient: Indonesian Journal of Development Economics, 3(1), 698-709. https://doi.org/10.15294/efficient.v3i1.35971

(C) 2019 Semarang State University. All rights reserved

\footnotetext{
Alamat Korespondensi :

Alamat: Gedung L2 Lantai 2 FE Unnes

Kampus Sekaran, Gunungpati, Semarang, 50229

E-mail : efficientjournal@gmail.com
}

ISSN 2655-6197 


\section{INTRODUCTION}

The issue of stability in rice prices is important to note because it guarantees the availability of rice in consumer households and influences regional stability (Wibowo et al., 2015). Stable rice prices can also prevent poor farmers and consumers from falling into the poverty trap (Dawe \& Timmer, 2012). However, the stable price of rice is not enough because if the price of rice is stable but the price is not affordable to the people, the stability of rice prices can make the poor people miserable.

The average price of rice in Indonesia is very high compared to the average price of international rice, namely the price of rice in Indonesia of US $\$ 1 / \mathrm{kg}$ and the average international rice price of US \$ 0.4 / kg (Idris, 2017). There is an assumption that high rice prices can benefit farmers, but distributors are the ones who benefit the most (Obayelu, 2011) and the largest distribution of marketing margins is in the rice mill and middlemen (Ariwibowo, 2013).

Therefore, to address the problem of stability, affordability of prices and unfavorable distribution of profit margins next to the parties, the government needs to make a direct pricing policy on rice commodities through the Regulation of the Minister of Trade of the Republic of Indonesia No. 57 / MDAG / PER / 8/2017 concerning Determination of the Highest Retail Price of Rice or commonly called the HET policy of rice to maintain the stability and certainty of rice prices, and affordability of rice prices at consumers. The policy will take effect on September 1, 2017, starting from traditional markets to modern retailers. This rice HET is regulated based on zoning. Java, Lampung, South Sumatra, Bali, NTB and Sulawesi are considered as rice producer regions. So that in these areas the price of medium rice is set at $\mathrm{Rp}$ 9,450 / kg and premium is $\mathrm{Rp} \mathrm{12,800} \mathrm{/} \mathrm{kg.}$ While for other regions that require more transportation costs, the price is added to Rp5oo. In the HET rice policy, every rice seller in retail to consumers must follow the HET rules that have been made and must bear the consequences of administrative sanctions if the sellers violate them. The sanction is in the form of revoking business licenses by officials issuing permits after receiving a maximum written warning twice from the issuing permit official.

Table 1. Information on Medium Rice Prices in the Provincial Capital of Java Island August - December 2017 Period

\begin{tabular}{llllllllc}
\hline \multirow{2}{*}{ No } & The City & $\begin{array}{l}\text { August } \\
(\mathrm{Rp})\end{array}$ & $\begin{array}{l}\text { September } \\
(\mathrm{Rp})\end{array}$ & $\begin{array}{l}\text { October } \\
(\mathrm{Rp})\end{array}$ & $\begin{array}{l}\text { November } \\
(\mathrm{Rp})\end{array}$ & $\begin{array}{l}\text { December } \\
(\mathrm{Rp})\end{array}$ & \multicolumn{2}{c}{ Change } \\
\cline { 7 - 9 } & DKI Jakarta & $\mathbf{1 1 . 0 8 0}$ & $\mathbf{1 1 . 0 2 9}$ & 10.900 & 10.784 & 10.705 & -375 & -3.39 \\
$\mathbf{2}$ & Bandung & 10.000 & 10.000 & 10.000 & 10.000 & 10.425 & 425 & 4.25 \\
3 & Semarang & 9.454 & 9.697 & 9.928 & 9.938 & 10.604 & 1.150 & 12.16 \\
4 & Serang & 9.828 & 9.990 & 10.000 & 10.000 & 10.155 & 327 & 3.33 \\
5 & Surabaya & 9.346 & 9.357 & 9.359 & 9.384 & 9.336 & -10 & -0.11 \\
6 & Yogyakarta & 9.024 & 9.212 & 9.395 & 9.610 & 10.083 & 1.059 & 11.74 \\
\hline
\end{tabular}

Source : SP2KP (2018) 
In Indonesia, if seen by island, the contribution of agricultural households in Java is 76.4 percent (BPS, 2014). This should make the price of rice affordable. However, based on table 1 , medium rice prices in various capitals on Java Island during August to December 2017 mostly experience varying price increases, some even exceed the highest retail prices determined by the government. The biggest price increase occurred in Semarang City at $12.16 \%$ followed by Yogyakarta City at $11.74 \%$. While other cities have relatively small price increases, Bandung City rose by $4.25 \%$, Serang City increased by $3.33 \%$ even in Jakarta City medium rice prices decreased by $3.39 \%$ and Surabaya City fell by $0.11 \%$.

Table 2. Information on Medium Rice Prices in the Provincial Capital of Java Island August - December 2016 Period

\begin{tabular}{lllllllll}
\hline No & The City & $\begin{array}{l}\text { August } \\
(\mathrm{Rp})\end{array}$ & $\begin{array}{l}\text { September } \\
(\mathrm{Rp})\end{array}$ & $\begin{array}{l}\text { October } \\
(\mathrm{Rp})\end{array}$ & $\begin{array}{l}\text { November } \\
(\mathrm{Rp})\end{array}$ & $\begin{array}{l}\text { December } \\
(\mathrm{Rp})\end{array}$ & \multicolumn{2}{c}{ Change } \\
\cline { 8 - 10 } & DKI Jakarta & 10.798 & 10.673 & 10.591 & 10.591 & 10.603 & -195 & $-0,018$ \\
2 & Bandung & 10.012 & 10.000 & 10.000 & 10.000 & 10.000 & -12 & $-0,001$ \\
3 & Semarang & 9.517 & 9.517 & 9.517 & 9.517 & 9.517 & 0 & o \\
4 & Serang & 10.000 & 10.000 & 10.000 & 10.000 & 10.000 & 0 & o \\
5 & Surabaya & 9.291 & 9.311 & 9.404 & 9.468 & 9.458 & 167 & 0,017 \\
6 & Yogyakarta & 9.319 & 9.338 & 9.422 & 9.405 & 9.425 & 106 & o,o11 \\
\hline
\end{tabular}

Source : $\mathrm{SP}_{2} \mathrm{KP}(2018)$

Even if you see the price of medium rice in the same month period in 2016 as in table 2 where the highest retail price policy for rice has not been implemented. The price of medium rice in the city of Semarang has not changed, amounting to Rp. 9,517.0o. And the biggest increase in prices occurred in the city of Surabaya from Rp 9,291.oo to Rp 9,458.oo. This indicates that the price of medium rice in the city of Semarang responds to the HET policy negatively or is not in accordance with the objective of the implementation of the rice HET policy.

Based on these problems. research on the strategy of implementing the Highest Retail Price Policy for Rice, especially medium rice in the city of Semarang, is important to overcome this problem.

\section{RESEARCH METHODS}

In this study using a qualitative approach because it aims to explore an object of research. A qualitative approach is used if the research problem is not clearly known. (Sugiyono, 2015). The data used in this study are primary data and secondary data. This study focuses on the scope of analysis of internal and external factors that are advantages, weaknesses, opportunities and threats to policy. Then the strategy formulation is carried out to implement the 
policy of the highest retail price of rice in the city of Semarang.

The technique of collecting data uses interview techniques and questionnaires. Speakers from the Semarang City Trade Service, Semarang Subdivre BULOG, and rice sellers. SWOT analysis is used to formulate appropriate policy implementation strategies. SWT analysis is a data analysis tool used to formulate strategies by analyzing strengths, weaknesses, opportunities and threats (DWP et al., 2009). In the SWOT analysis there are stages of data input, data matching and decision making.

\section{RESULTS AND DISCUSSION}

The opportunity factor itself is the government's ability to increase the supply of rice by importing $\left(\mathrm{O}_{1}\right)$, the government's readiness to fill rice in the market if there is a shortage ( $\left.\mathrm{O}_{2}\right)$ and encouraging the community to maintain rice price stability $\left(\mathrm{O}_{3}\right)$. While threat factors consist of limited availability of rice $\left(\mathrm{T}_{1}\right)$, disruption of factors that affect rice production ( $\left.\mathrm{T}_{2}\right)$ and long rice distribution chain $\left(\mathrm{T}_{3}\right)$. Using EFAS (External Factors Analysis Summary) or External Factor Strategy is a method in SWOT analysis that uses external factors such as opportunities and threats.

Table 3. External Factors Analysis Summary

\begin{tabular}{lllll}
\hline No. & Opportunity $(\mathrm{O})$ & Weight & Rating & Weight x Rating(Score) \\
\hline $\mathbf{1}$ & O1 & 0,1111 & 2,7 & 0,2963 \\
2 & O2 & 0,1389 & 3,0 & 0,4167 \\
3 & O3 & 0,1667 & 2,3 & 0,3889 \\
& SUB TOTAL & 0,4167 & 8 & 1,1019 \\
No & Threat (T) & & & \\
1 & T1 & 0,1611 & 2,7 & 0,4296 \\
2 & T2 & 0,2000 & 2,3 & 0,4667 \\
3 & T3 & 0,222 & 3,7 & 0,8148 \\
& SUB TOTAL & 0,5833 & 8,7 & 1,7111 \\
& TOTAL O+T & 1,0 & & 2,8130 \\
\hline
\end{tabular}

Source: (Primary Data, processed 2018)

As in table 3. the Opportunity score of 1.1019 can be obtained greater than the Threat score of 1.7111, so it can be assumed that the implementation of the HET rice policy has many threats rather than opportunities. The biggest threat is the threat of $\mathrm{T}_{3}$ (Long Rice Distribution Chain) with a score of 0.7875 . While the biggest opportunity is in $\mathrm{O}_{2}$ (the government is ready to fill rice in the market if there is a shortage) with a score of 0.5250 .

The increase in the price of medium rice which exceeds the highest retail price of rice that has been determined is more due to the long distribution chain of rice. The length of the distribution chain occurs because the city 
of Semarang in general is not an area that depends its economy on the agricultural sector but has become an industrial area which is characterized by the large number of industrial areas in the city of Semarang. This has caused the available resources to be aimed more at the industrial sector with calculations that are more profitable than those used for other sectors such as the agricultural sector for food. So that to meet their food needs, the people of Semarang City depend on their hopes for agriculture in the surrounding area. Dependence is what causes the rice distribution chain in the city of Semarang to be long, which is simply a rice distribution chain from farmers outside the city of Semarang sold to collectors in the city and then to collectors in Semarang and forwarded to large traders before arriving at the traders. small or retail trader.

While the biggest opportunity for implementing the rice HET policy is in the government's readiness to fill or increase rice supply on the market if there is a shortage. The addition of rice to the market is done through market operations by BULOG. In this case, the city of Semarang is handled by the Subdivre of Semarang Regional Logistics Bureau. In market operations carried out in Semarang City, BULOG supplies rice to rice traders in the market in Semarang City. This operation is carried out at certain times such as Eid Al-Fitr, Christmas and New Year and at times when it is needed. There are no specific criteria so that rice traders on the market can get rice from BULOG.

Rice from BULOG itself is sold to traders at prices below HET. For medium rice, BULOG sells it to traders in the amount of IDR $8,500.00$ and for premium rice is sold at IDR 9,500 to IDR 10.00,0o. It is expected that this program can make the price of medium rice fall below the highest retail price because the distribution chain becomes shorter. Namely from farmers in the area around Semarang City directly to the Bureau of Logistics and from BULOG directly to traders.

Strength factors consisting of ease of policy to be published ( $\left.\mathrm{S}_{1}\right)$, adequate human resources $\left(\mathrm{S}_{2}\right)$, clear goals and policy objectives (S3) and clear sanctions for policy violators. While the weakness factor consists of the level of supervision of the implementation of policies that have not been optimal (W1), the executor rejects the policy (W2), the highest retail price level that is not right $\left(\mathrm{W}_{3}\right)$ and policy information has not been conveyed clearly to all implementers $\left(\mathrm{W}_{4}\right)$. Table 4.5 is a table obtained from weighting and tabulated rating. Weighting and rating are carried out by 
keyperson from Semarang City Trade Service, Semarang Subdivre BULOG, rice distributor and retail rice seller in Semarang City.

Data processing is done by using Microsoft Excel application by entering weighting numbers and ratings that have been filled in by keyperson. The researcher tabulates the weighting number and rating of each keyperson. To obtain the weighting rate and overall rating, all weighting numbers and the entire keyperson rating are averaged to get IFA
From table 4. the weakness score of 1.5666 is greater than the strength score of 1.4911, so it can be assumed that the implementation of the HET rice policy has many weaknesses rather than its strength. The biggest disadvantage is the weakness of $\mathrm{W}_{1}$ (Level of supervision of the implementation of policies that are not optimal) with a score of o.5129. While the greatest strength is in $\mathrm{S} 1$ (easily published policy) with a score of 0.4911 .

Table 4. Internal Factors Analysis Summary

\begin{tabular}{lllll}
\hline No. & Strength (S) & Weight & Rating & Weight x rating (Score) \\
\hline $\mathbf{1}$ & S1 & 0,1339 & 3,7 & 0,4911 \\
$\mathbf{2}$ & S2 & 0,1012 & 3 & 0,3036 \\
3 & S3 & 0,1190 & 3 & 0,3571 \\
4 & S4 & 0,1131 & 3 & 0,3393 \\
& SUB TOTAL & 0,4672 & 12,7 & 1,4911 \\
No & Weakness (W) & & & \\
1 & W1 & 0,1399 & 3,7 & 0,5129 \\
2 & W2 & 0,1251 & 2 & 0,2501 \\
3 & W3 & 0,1339 & 3 & 0,4018 \\
4 & W4 & 0,1339 & 3 & 0,4018 \\
& SUB TOTAL & 0,5328 & 11,7 & 1,5666 \\
& TOTAL S+W & 1,0 & & 3,0576 \\
\hline
\end{tabular}

Source: (Primary Data, processed 2018)

From the Semarang City Trade Office the level of supervision is less than optimal due to limited human resources who also deal with problems in the market. From the office, employees who go directly to the market are only limited to one market person and that is only the big markets that are the working area. So that not all markets can be affordable by the Semarang City Trade Service.
While the dominating force factor is the ease of policy can be published. This is supported by technological advancements and times that make almost anyone can operate a smart phone. Through these smart phones, almost all information can be obtained. So that when the policy of determining rice HET was established, almost all the people of Semarang city could find out. 
Analysis The SWOT matrix consists of previously described first by using the space SO (Strength Opportunity), WO (Weakness matrix which is used to determine the strategic Opportunity), ST (Strength Threath), WO direction of development then formulated in (Weakness Opportunity). The matrix was the SWOT matrix.

Table 5. Matrix Space

\begin{tabular}{|c|c|c|c|}
\hline Internal Strategy Factors & $\begin{array}{l}\text { Average } \\
\text { rating }\end{array}$ & External Strategy Factors & $\begin{array}{l}\text { Average } \\
\text { rating }\end{array}$ \\
\hline Strength (S): & & Opportunity $(\mathrm{O})$ : & \\
\hline 1. Easy Published Policy & 3,0 & $\begin{array}{l}\text { 1. Ability to Increase the } \\
\text { Supply of Rice with Rice }\end{array}$ & 2,7 \\
\hline 2. Adequate Human Resources & 3,0 & Imports & \\
\hline $\begin{array}{l}\text { 3. Clear Policy Objectives and } \\
\text { Objectives }\end{array}$ & 3,0 & $\begin{array}{l}\text { 2. The Government Is Ready } \\
\text { to Fill Rice in the Market if } \\
\text { Shortages Occur }\end{array}$ & 3,0 \\
\hline $\begin{array}{l}\text { 4. Clear Sanctions for Policy } \\
\text { Offenders }\end{array}$ & & $\begin{array}{l}\text { 3. The Community's } \\
\text { Encouragement to Maintain } \\
\text { Rice Price Stabilization }\end{array}$ & 2,3 \\
\hline $\begin{array}{l}\text { Total Strength } \\
\text { Weakness (W): }\end{array}$ & 11,7 & $\begin{array}{l}\text { Total Opportunity } \\
\text { Threat }(\mathrm{T}) \text { : }\end{array}$ & 8,0 \\
\hline $\begin{array}{l}\text { 1. Level of Supervision of } \\
\text { Implementation of Policies that } \\
\text { Are Not Optimal }\end{array}$ & 3,7 & $\begin{array}{l}\text { 1. Availability of Limited Rice } \\
\text { 2. Disorders of Factors } \\
\text { Affecting Rice Production }\end{array}$ & $\begin{array}{l}2,7 \\
2,3\end{array}$ \\
\hline $\begin{array}{l}\text { 2. Implementers Refuse Policy } \\
\text { 3. The highest level of retail price }\end{array}$ & 2,7 & $\begin{array}{l}\text { 3. Long Rice Distribution } \\
\text { Chain }\end{array}$ & 3,7 \\
\hline $\begin{array}{l}\text { that is not right } \\
\text { 4. Policy Information Has Not } \\
\text { Been Delivered Clearly to All } \\
\text { Executors }\end{array}$ & 3,3 & & \\
\hline Total Weakness & 12,7 & Total Threat & 8,7 \\
\hline
\end{tabular}

Source: (Primary Data, processed 2018)

The Space Strategy for the a rating of 11.7 and weaknesses with a implementation of medium rice HET policy in rating of 12.7. Whereas external strategic the city of Semarang can be explained that factors include opportunities with a rating internal strategy factors include strength with $\quad$ of 8.0 and threats with a rating of 8.7. 
After calculating the rating on each While the weakness is the number of rating factor, the next step is to calculate through recapitulation of the average strengths, weaknesses, opportunities, and threats. The recapitulation of these calculations is explained in table 6 in the appendix.

Recapitulation of the results of calculating average strengths, weaknesses, opportunities, threats is obtained by dividing the number of ratings with the strategies of each internal and external factor (Damayanti, 2017). Internal factors which include strength, namely with a rating of 11.7 divided by 4 strength factors, obtained a value of $\mathbf{2 . 9 2 5}$. 12.7 divided by 4 weakness factors, the value obtained is 3.175. External factors that include opportunities, namely with a rating of 8 divided by 3 opportunity factors obtained a value of 2.67. While the threat with a number of rating 8.7 divided by 3 threat factors then obtained a value of 2.9. After obtaining the value of each factor, then determine the strategy by determining the axis point:

Internal factors

Strengths - Weaknesses 2,925 - 3,175 $=-0,25$

External Factors :

Opportunity-Threat 2.67-2.9 =-0.23.

Table 6. Recapitulation of Average Strengths, Weaknesses, Opportunities, and Threats

\begin{tabular}{lll}
\hline No. & \multicolumn{1}{c}{ Description } & Value \\
\hline 1 & Internal factors : & 2,925 \\
& a. Power & 3,175 \\
& b. Weakness & \\
2 & External Factors: & 2,67 \\
& a. Opportunity & 2,9 \\
& b. Threat &
\end{tabular}

Source: (Primary Data, processed 2018)

Based on Figure 1, the strategy for factor = 2.9. So that the coordinates $(-0.25$; implementing the medium rice HET policy in 0.23 ) are found in the quadrant 4 . It is a very the city of Semarang obtained a weighting unfavorable situation where the score for the strength factor $=\mathbf{2 . 9 2 5}$ weakness implementation of policies faces various factor $=3.175$ opportunity factor $=\mathbf{2} .67$ threat threats and weaknesses. This requires 
maintaining the position or at least having to policy can be carried out properly. survive so that the implementation of the

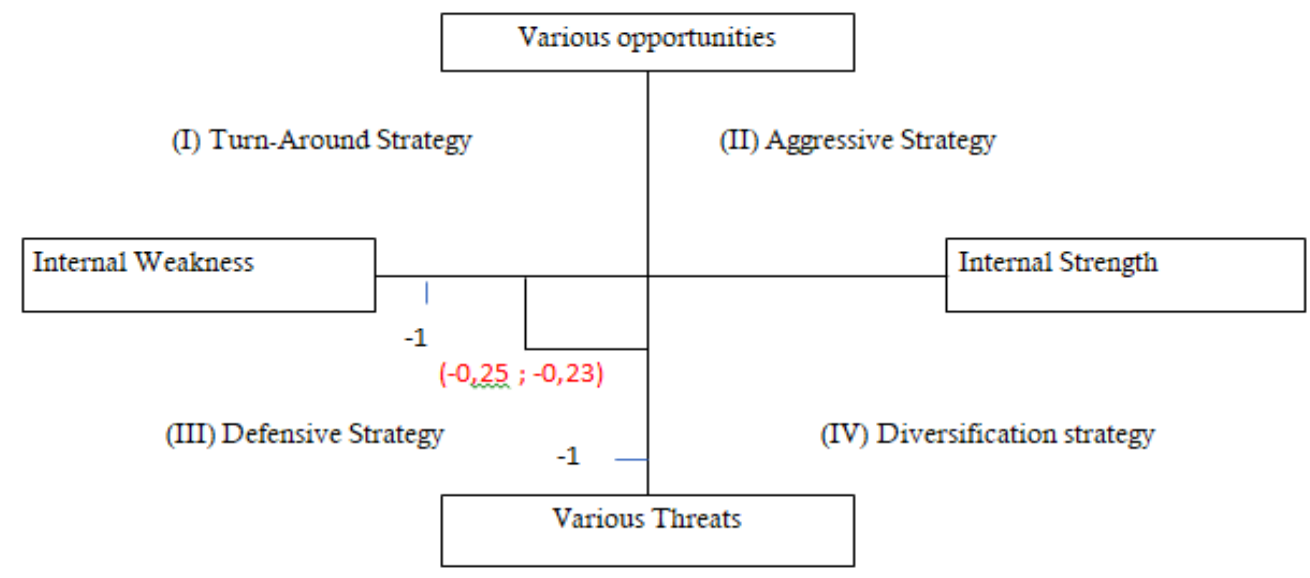

Figure 1. Calculation of Average Strengths, Weaknesses, Opportunities, and Threats Source: (Primary Data, processed 2018)

The strategy that the government needs to implement is a defensive strategy. Defensive strategy is a strategy used to deal with weaknesses and threats (Rangkuti, 2014). In table 4, the biggest weakness that needs to be overcome is $W_{1}$ (the level of supervision of policy implementation that is not optimal). This weakness arises because of the lack of supervisory staff in the field and to overcome this need to involve the community to be a supervisor of the implementation of HET rice policy in Semarang City by reporting rice traders who sell rice above the highest retail price.

In table 3, the biggest threat faced is $\mathrm{T}_{3}$ (long rice distribution chain). In facing this threat, the government needs to urge rice sellers in Semarang to buy rice from the Logistics Bureau. So that rice sellers do not get rice from BULOG when there is only market operations. Rice in BULOG is rice obtained from farmers. So that the rice distribution chain becomes shorter, from farmers to BULOG, it continues to retail rice traders on the market.

In addition to defensive strategies, there are several strategies that can be implemented by the government so that policy implementation can be carried out properly, namely:

\section{SO Strategy}

The strategy is to use force to take advantage of opportunities by intensifying the publication of medium rice prices supplied by the government through Logistics Bureau so that consumers can bargain clearly. Because with complete information in the form of medium rice prices paid by traders to BULOG, consumers can consider for themselves the 
appropriate price margins obtained by medium rice traders.

\section{WO Strategy}

The strategy is done by overcoming weaknesses by taking advantage of opportunities. One of the WO strategies that can be done is to provide an opportunity for the community to participate in maintaining price stability by making people able to actively participate in monitoring and reporting medium rice sellers who sell medium rice at unreasonable prices.

\section{ST strategy}

The strategy is to use force to avoid threats by directing traders if at any time there is a surge in the price of rice being expensive above the highest retail price to buy rice directly to BULOG. This needs to be done so that the long rice distribution chain can be cut off. So that the margin generated from the distribution chain is not too large.

\section{WT Strategy}

Strategies to minimize weaknesses and avoid threats from the implementation of medium rice HET policies, namely by calling on rice traders to buy rice to BULOG without waiting for market operations and marking traders selling rice obtained from BULOG and asking consumers to give an assessment of these traders. Because rice supplied by the government should be able to be sold not to exceed the determined HET of rice. But medium rice from the government when it was released to the market for Rp. 8,50o but up to consumers of more than Rp. 9,450. This indicates a very high price margin taken by traders. In addition, a binding agreement between traders and BULOG is needed if there is an indication that traders are taking too large profit margins.

\section{CONCLUSION}

Based on the results and discussion of the research about the strategy of implementing the highest retail price policy for medium rice in the city of Semarang. Then some conclusions can be drawn as follows:

Internal factors and influencing external factors, namely in terms of strength in internal factors consisting of easily publicized policies, adequate human resources, policy objectives and clear sanctions for policy violators. The weakness side is that the level of supervision is not optimal, the implementer rejects the policy, the highest level of retail price is not right and policy information has not been clearly conveyed. While the opportunity side of external factors is the ability to increase the supply of rice with imports, the readiness of the government to fill rice in the market and encouragement of the community to maintain stability in rice price stability. The threat side is the availability of rice from limited farmers, the disruption of the factors of rice production and the long rice distribution chain.

Implementation of the highest rice retail price policy in a situation that is less profitable because it is dominated by factors that become threats and weaknesses, a defensive strategy is needed to overcome these threats and weaknesses. Especially to overcome weaknesses in the form of supervision that is not optimal and overcome the threat of a long rice distribution chain. 


\section{REFERENCES}

Ariwibowo, A., 2013. Analisis Rantai Distribusi Komoditas Padi Dan Beras Di Kecamatan Pati Kabupaten Pati. Economics Development Analysis Journal, 2(2).

Damayanti, Nadia. 2017. Strategi Pengembangan Kerjasama Sister City Semarang, Indonesia Brisbane, Australia. Skripsi. Semarang: Universitas Negeri Semarang.Dawe, D. \& Timmer, , 2012. Why stable food prices are a good thing: Lessons from stabilizing rice prices in Asia. Global Food Security, Volume 1(Issue 2), pp.Pages 127-133.

DWP, S., Sutrasmawati, E. \& SW, I.F., 2009. Analisis Persepsi Dan Preferensi Ibu Rumah Tangga Terhadap Produk Pangan Olahan Berbasis Tepung Ubi Jalar Dalam Meningkatkan Keanekaragaman Pangan. Jurnal Ekonomi dan Kebijakan, 2(1).
Idris, M., 2017. detikfinance. [Online] Available at: //finance.detik.com/berita-ekonomi-bisnis/d3534836/ri-produsen-beras-no3-dunia-tapiharganya-mahal-kok-bisa [Accessed 20 Januari 2018].

Obayelu, A.E., 2011. Cross-countries analysis of rising food prices: policy responses and implications on emerging markets. International Journal of Emerging Markets, Vol. 6(Issue: 3), pp.pp.254-275.

Sugiyono, 2015. Metode Penelitian Kuantitatif Kualitatif $R \mathcal{E} B$. Bandung: Aflabeta.

Wibowo, D., Moeis, O., Wiguna, C.B. \& Chaulan, T.A.C., 2015. Policy Model of Production and Price of Rice in Kalimantan Selatan. Agriculture and Agricultural Science Procedia, Volume 3, pp.Pages 266-273. 


\section{APPENDIX}

Tabel 7. Analisis SWOT

\begin{tabular}{|c|c|c|}
\hline EKSTERNAL & $\begin{array}{l}\text { STRENGTH (S) } \\
\text { 1. Clear Policy Objectives } \\
\text { and Objectives } \\
\text { 2. Adequate Human } \\
\text { Resources } \\
\text { 3. Easy Published Policy } \\
\text { 4. Clear Sanctions for } \\
\text { Policy Offenders }\end{array}$ & $\begin{array}{l}\text { WEAKNESS (W) } \\
\text { 1. Level of Supervision of } \\
\text { Implementation of Policies that Are } \\
\text { Not Optimal } \\
\text { 2. Implementers Refuse Policy } \\
\text { 3. The highest level of retail price } \\
\text { that is not right } \\
\text { 4. Policy Information Has Not Been } \\
\text { Delivered Clearly to All Executors }\end{array}$ \\
\hline $\begin{array}{l}\text { OPPORTUNITY }(\mathrm{O}) \\
\text { 1. Ability to Increase the } \\
\text { Supply of Rice with Rice } \\
\text { Imports } \\
\text { 2. The Government Is } \\
\text { Ready to Fill Rice in the } \\
\text { Market if Shortages Occur } \\
\text { 3. The Community's } \\
\text { Encouragement to } \\
\text { Maintain Rice Price } \\
\text { Stabilization }\end{array}$ & $\begin{array}{l}\text { SO STRATEGY } \\
\text { 1. To intensify the } \\
\text { publication of medium rice } \\
\text { prices supplied by the } \\
\text { government through } \\
\text { Logistics Bureau so that } \\
\text { consumers can bargain } \\
\text { clearly. }\end{array}$ & $\begin{array}{l}\text { WO STRATEGY } \\
\text { 1. Give an opportunity to the } \\
\text { community to participate in } \\
\text { maintaining price stability by } \\
\text { actively participating in monitoring } \\
\text { and reporting on prices and } \\
\text { abnormal rice traders. }\end{array}$ \\
\hline $\begin{array}{l}\text { THREAT (T) } \\
\text { 1. Availability of Limited } \\
\text { Rice } \\
\text { 2. Disorders of Factors } \\
\text { Affecting Rice Production } \\
\text { 3. Long Rice Distribution } \\
\text { Chain }\end{array}$ & $\begin{array}{l}\text { STRATEGY ST } \\
\text { 1. Direct the trader if at any } \\
\text { time there is a surge in the } \\
\text { price of rice or when the } \\
\text { rice becomes expensive } \\
\text { above the price of the } \\
\text { provisions to buy rice } \\
\text { directly to the Bureau of } \\
\text { Logistics. }\end{array}$ & $\begin{array}{l}\text { WT STRATEGY } \\
\text { 1 Appealing to traders to buy rice to } \\
\text { the Bureau of Logistics without } \\
\text { waiting for market operations and } \\
\text { marking traders selling rice from } \\
\text { the Bureau of Logistics and asking } \\
\text { consumers to give an assessment of } \\
\text { these traders. }\end{array}$ \\
\hline
\end{tabular}

Source: (Primary Data, processed 2018) 